\title{
Identification of Guidance and Counseling Service Needs for Higher Education Students at Universitas Negeri Yogyakarta
}

\author{
Diana Septi Purnama* \\ Program Studi Bimbingan dan Konseling \\ Universitas Negeri Yogyakarta \\ Yogyakarta, Indonesia \\ dianaseptipurnama@uny.ac.id*
}

\author{
Muh Farozin \\ Program Studi Bimbingan dan Konseling \\ Universitas Negeri Yogyakarta \\ Yogyakarta, Indonesia \\ farozin2311@yahoo.com
}

\author{
Budi Astuti \\ Program Studi Bimbingan dan Konseling \\ Universitas Negeri Yogyakarta \\ Yogyakarta, Indonesia \\ budi_astuti@uny.ac.id
}

\begin{abstract}
This study was aimed to identify the need for guidance and counseling services at Yogyakarta State University students. This research is a quantitative research with survey research type. The study population was all students of Yogyakarta State University at the Bachelor's level. The research sample was taken as a number of 344 students from 7 faculties at UNY. The sampling technique uses simple random sampling. Data collection used a questionnaire. Data analysis techniques used quantitative descriptive techniques. The results showed that the level of guidance and counseling service needs of UNY students as a whole were in the low category. The need of guidance and counseling Service on 210 UNY student are at low category $(61 \%)$ while 134 student $(39 \%)$ are at medium category. Based on demographics namely gender the level of guidance and counseling service needs of female students is higher, the level of guidance and counseling service needs of students from the 2017 generation is higher than that of other batches, the level of guidance and counseling service needs of Social Sciences faculty students is higher compared to other faculties. This research has implications for the Technical Implementation Unit of Guidance and Counseling Services of Yogyakarta State University to optimize guidance and counseling services so that their existence provides benefits for the fulfillment of the needs and tasks of student development.
\end{abstract}

Keywords - the need for guidance \& counseling services, higher education students

\section{INTRODUCTION}

The Guidance and Counseling Service Technical Implementation Unit, Yogyakarta State University (UPT LBK UNY) is a unit that aims to serve UNY students in dealing with psychological, academic, social and career determination problems in the future. The purpose of the study was to analyze the needs of UNY students towards LBK UPT and the profile of student problems and their coping strategies. Student life at university is life that has certain characteristics, a new environment that is different from the previous school environment will trigger anxiety and cause stress both in our country and in other countries. Students are people who experience problems related to their developmental period because students start entering the university during adolescence so that in terms of development they are sometimes treated as children and sometimes as adults in their environment. The most important thing that is expected of them is independence. The university is an environment that is vulnerable to creating stress for adolescents who are still in the formation of identity [1].

There are several needs to meet the requirements for developing human resources. Therefore, universities strive to train quality human resources, must also find the source of their problems and find solutions for the development of their personalities and give them knowledge, skills, ideals and habits of good students. University environment is an environment that has demands and expectations for students. Students who never get lessons about good values, attitudes, and habits will experience difficulties in carrying out their lives as students. This situation is even more dramatic for students who come from small cities to universities which generally are in big cities.

Many studies conducted on students show the results that while the needs of students are mostly increasing in the academic field, problems of misdirection and psychological problems, the needs of students may vary depending on socioeconomic status, gender, socio-cultural and cultural trends or subcultures where they are located [2]. Students have many difficulties in daily life such as; overcoming laziness, public speaking anxiety, career uncertainty, efficient learning skills, lack of motivation, self-confidence issues, test anxiety, fear of failure, depression, problems experienced by the opposite sex and time management [3. 4]. Likewise, study mentioned problems such as; fear of failure, overcoming procrastination, depression, discomfort in the social environment and overcoming loneliness among students in South Africa [5]. Problems are experienced in academics/educational problems such as; efficient study skills, focused attention, time management and test anxiety among university students in Spain [6].

The purpose of guidance and counseling services provided to students in higher education is not only to overcome psychological disorders and healing with therapy but also to support the development of a healthy identity. Incorrect understanding that students who have been enrolled in tertiary institutions have chosen their careers and 
professions appropriately and no longer need professional guidance from counselors. Many college graduates find it difficult to find jobs related to their fields after completing their studies. One area of guidance and counseling services is career and academic guidance and counseling. Activities such as career orientation, helping to make the right decisions, assistance to overcome test anxiety and efficient self-development and learning skills in guidance and counseling services make it easy for students to find out about the educational institution and to find out more about what material they will learn and practice in their chosen field so that students are familiar with academic life on campus and are skilled in managing time and adapting to the campus environment [1].

UPT LBK gives students the opportunity to utilize their energy and time more efficiently. Counseling services are provided to students for the development of individual personalities, overcoming personal, social, academic and career problems so that the UPT LBK is effective in helping students to smooth their studies. The effectiveness of the LBK UPT can be seen in the following criteria: (a) promoting the campus/university and giving orientation to students about the function of the UPT LBK at the university, (b) providing information about efficient learning skills, (c) helping them overcome exam anxiety, (d) dealing with students.

\section{METHODS}

The research approach used in this research is quantitative research with survey research. The study population was all undergraduate students of Yogyakarta State University. Based on data from the Higher Education Database (PDPT), the Ministry of Research, Technology and Higher Education in the academic year 2017/2018 it is known that the total number of UNY S1 students with active status is 22,233 students. The research sample is part of the population with sampling techniques using simple random sampling.

This study uses an instrument in the form of a questionnaire. The questionnaire aims to capture and identify the needs of guidance and counseling services for students. Then the data is processed, analyzed and interpreted.

The research instrument was in the form of a questionnaire that revealed the needs of guidance and counseling services for students. The aspects revealed were the profile of student problems, BK service expectations, coping strategies and problem solving.

The data analysis technique was carried out using quantitative analysis and was described to find a picture of identifying the needs of guidance and counseling services for UNY students.

\section{DISCUSSION}

The results showed that the level of need for guidance and counseling services for UNY students as a whole was in the low category of 210 people $(61.05 \%)$. This research explains that the majority of UNY students are able to solve their own problems without the help of guidance and counseling services. This is in contrast with research conducted on students of the Koaceli University of Turkey regarding the identification of psychological guidance and counseling services. This study explained that Turkish Koaceli University students have a positive perception of guidance and counseling services so that students' needs for guidance and counseling services are also high [1]. Other research that is also opposite is the research conducted at Ankara University on Faculty of Education students, explaining that the need for guidance and counseling services is high, especially in several key aspects such as academic, relationship, emotional, and career issues [7].

The need for guidance and counseling services for students in tertiary institutions is a form of need for psychological assistance provided by a professional who has expertise and authority in providing guidance and counseling services to individuals or groups of individuals who are in Higher Education institutions that aim to solve difficulties difficulties, obstacles, obstacles, challenges that are often experienced by students so that they can develop optimally in accordance with their potential [8]. The low needs of students for guidance and counseling services in higher education can be caused by several reasons. Based on the results of research states that there are several reasons students do not need counseling guidance services in tertiary institutions, half of them $(50 \%)$ answered that they are adults, can solve their own problems, a small portion (12.9\%) answered not too needed/unnecessary, there is also a small percentage of reasons that counseling guidance services are for junior high schools and high schools and have nothing to do with their majors $(5.5 \%)$ [8]. On the other hand, there were also reasons for the answers of students who needed counseling guidance services, almost half $(25.10 \%)$ answered helping students solve problems, a small portion $(19.45 \%)$ to consult about the problem/confide/share, and there were also a small portion $(11.09 \%)$ reasoned for better direction and formation of student/character/personal maturity.

The level of guidance and counseling service needs of the majority of male students of UNY is in the low category, namely 91 people $(68.4 \%)$ and 42 people $(31.6 \%)$ are in the medium category, and none are classified in the high category $(0.0 \%)$. This result is almost the same as female students with the level of need for guidance and counseling services as many as 119 people $(56.4 \%)$ are in the low category, while 92 people $(43.6 \%)$ are in the moderate category. The results of this study indicate that the need for guidance and counseling services for female students is higher than male students. This supports research conducted on Turkish Koaceli University students regarding the identification of psychological counseling and guidance services that show that the need for guidance and counseling services for women is higher than for men [1].

Discussion of this study analyzed from various studies of the results of the research, it seemed that it was deemed necessary to optimize the performance of the guidance and counseling service units in tertiary institutions. In this study, it is also necessary to follow up with the collection of data that causes the low need for student 
guidance and counseling services. In the research instruments compiled by researchers, there are limitations to the research, namely aspects of student problem profiles, expectations of BK services, coping strategies and problem solving. These aspects do not include the factors that influence the level of need for guidance and counseling services as well as the causes of the need for guidance and counseling services for UNY students. Therefore, it is necessary to follow up in order to improve the results of this study.

\section{CONCLUSION}

The results showed that the level of guidance and counseling service needs of UNY students as a whole were in the low category. Based on demographics namely gender the level of guidance and counseling service needs of female students is higher, the level of guidance and counseling service needs of students from the 2017 generation is higher than that of other batches, the level of guidance and counseling service needs of Social Sciences faculty students is higher compared to other faculties.

\section{REFERENCES}

[1] Ulusoy et al. 293 Nicholas LJ. (2014). Determination of the needs of university students for psychological counseling and guidance services: The case of Kocaeli University, Turkey. Educational Research and Reviews . Vol. 9(10), pp. 286-293, 23 May, 2014 DOI: 10.5897/ERR2014.1746 ISSN 1990-3839.

[2] Papalia DE, Olds SW, Feldman RD. (2009). Human development. New York: McGrawHill.

[3] Gallagher R. (1992). Student needs survey have multiple benefits. J. College Student Dev. 33:281-282. Gallagher R,Golin A,Kelleher $\mathrm{K}(1992)$. The personal, career and learning needs of college students. J. College Student Dev. 33:301-309.

[4] Nicholas L, Damianova M. Ntantiso M. (2012). A comparison of South African and international first-year students' counselling needs and preferred counselling sources. Austr. J. Guidance Couns. 23(1):106114.

[5] Ulusoy et al. 293 Nicholas LJ. (2002). South African first year students' counseling needs and preferred counseling sources. Int. J. Adv. Couns. 24:289-295.

[6] Arco JL, Fernandez FD, Heilborn VA, Lopez S. (2005). Demographic, academic and psychological profile of students attending counseling services at the University of Granada (Spain). Int. J. Adv. Counsel. 27:71-85.

[7] Yalchin, I. \& Atik, G. (2010). Counseling needs of educationalsciences students at the Ankara University. Procedia Social and Behavioral Sciences 2 (2010) 1520-1526.

[8] Nastiti, Dwi, \& Habibah, Nur. (2016). Studi Eksplorasi Tentang Pentingnya Layanan Bimbingan Konseling Bagi Mahasiswa di Umsida. Psikologia (Jurnal Psikologi), 1 (1), July 2016, 52-78. ISSN 2338-8595 (print), ISSN 2541-2299 (online). Journal Homepage: http://ojs.umsida.ac.id/index.php/psikologia.DOI:10.21070/psikologia. v1i1.748. 